\title{
The Colorful Palette of Neuroendocrine Neoplasms in the Genitourinary Tract
}

\author{
BOGLÁRKA PÓSFAI ${ }^{1}$, LEVENTE KUTHI ${ }^{2}$, LINDA VARGA ${ }^{1}$, IBOLYA LACZÓ ${ }^{3}$, \\ JÁNOS RÉVÉSZ ${ }^{4}$, RÉKA KRÁNICZ ${ }^{1}$ and ANIKÓ MARÁZ ${ }^{1}$ \\ ${ }^{1}$ Department of Oncotherapy, University of Szeged, Szeged, Hungary; \\ ${ }^{2}$ Department of Pathology, University of Szeged, Szeged, Hungary; \\ ${ }^{3}$ Pándy Kálmán Hospital Gyula, Gyula, Hungary; \\ ${ }^{4}$ Institute of Radiotherapy and Clinical Oncology, \\ Borsod County Hospital and University Academic Hospital, Miskolc, Hungary
}

\begin{abstract}
Background: Neuroendocrine neoplasms include a heterogeneous group of malignant tumors. Primary neuroendocrine tumors in the genitourinary tract are rare, comprising approximately 1-2\% of genitourinary malignancies. Materials and Methods: An extensive search was performed for publications between 2000 and 2018 regarding neuroendocrine tumors of the genitourinary tract. Epidemiological, clinical, histopathological, prognostic and therapeutic data were evaluated. Results: Neuroendocrine tumors of the kidneys are exceedingly rare, mostly welldifferentiated. $0.5-1 \%$ of all primary bladder malignancies are small cell neuroendocrine carcinomas. Characteristically, prostatic adenocarcinoma with neuroendocrine differentiation occurs in androgen receptor-independent/castrate-resistant cancer. Small cell and large cell neuroendocrine carcinomas are the most aggressive tumors in each location. Conclusion: Due to the rarity and poor prognosis of these tumors, proper pathological diagnosis and early therapy are important. Therapeutic guidelines are not available. Surgery, radiotherapy and/or chemotherapy are possible treatment options; somatostatin analogs are used as standard therapy in case of well-differentiated neuroendocrine tumors.
\end{abstract}

This article is freely accessible online.

Correspondence to: Aniko Maraz, MD, Ph.D., Department of Oncotherapy, University of Szeged, Korányi Fasor 12, 6720 Szeged, Hungary. Tel: +36 62545404, Fax: +36 62545922, e-mail: dr.aniko.maraz@gmail.com

Key Words: Neuroendocrine tumor, small cell carcinoma, genitourinary neuroendocrine cancer, neuroendocrine prostate cancer, small cell prostate cancer, review.
Neuroendocrine neoplasms (NENs) make up a heterogeneous group of malignant tumors with distinct histological features, clinical behavior, and patient outcome. NENs can arise virtually in any organ system, although $85 \%$ of NENs affect the gastrointestinal (GI) tract and the lungs. Primary neuroendocrine tumors of the genitourinary (GU) tract are rare, accounting for less than $1-2 \%$ of $\mathrm{GU}$ malignancies $(1,2)$. Primary neuroendocrine tumors may develop anywhere in the GU tract; they are most frequently localized in the prostate, but the involvement of the kidneys, urinary bladder, testes, ovaries, and the uterus results in challenging diagnostic and therapeutic dilemmas. Otherwise, the GU tract is a potential site for metastases from other primary neuroendocrine tumors (3). On the basis of the 2016 World Health Organization (WHO) Classification of Tumors of Urinary System and Male Genital Organ classification system, they can be described as welldifferentiated neuroendocrine tumors (NET), large cell neuroendocrine carcinoma, small cell neuroendocrine carcinoma, and paraganglioma. The exact classification depends on the site of the origin (Table I) (4). Within this systematic review, the incidence, the pathological features, and prognostic data of NENs of the kidney, urinary bladder, and prostate are discussed together with an emphasis on the main differential diagnostic and therapeutic considerations. The various phenotypes are discussed below separately per organ. The morphological categorization is described by the WHO classification (Table I) (4).

\section{Materials and Methods}

PubMed database and clinical trials were searched with publication dates between January 2000 and January 2018. The keywords and the associated results include: The key word 'neuroendocrine genitourinary tumor', gave 656 results, out of which 181 were review papers, 358 pathology studies, and 117 case reports. The keyword 'neuroendocrine genitourinary tumor therapy', gave 314 papers. The search was 
Table I. World Health Organization (WHO) histological classification of neuroendocrine neoplasms of the genitourinary tract in adults (4).

\begin{tabular}{lcc}
\hline Kidney & Urinary Bladder & Prostate \\
\hline Well-differentiated neuroendocrine tumor & Well-differentiated neuroendocrine tumor & Adenocarcinoma with neuroendocrine differentiation \\
Small cell neuroendocrine carcinoma & Small cell neuroendocrine carcinoma & Well-differentiated neuroendocrine tumor \\
Large cell neuroendocrine carcinoma & Large cell neuroendocrine carcinoma & Small cell neuroendocrine carcinoma \\
Paraganglioma & Paraganglioma & Large cell neuroendocrine carcinoma \\
\hline
\end{tabular}

extended separately for the following organs. For 'neuroendocrine prostate tumor', 1130 papers were identified, and for 'neuroendocrine prostate carcinoma' 594 papers. 301 results were identified for the keyword 'neuroendocrine prostate tumor carcinoma therapy', and 211 for 'neuroendocrine urinary bladder tumor', 172 for 'neuroendocrine urinary bladder carcinoma', and 87 for 'neuroendocrine urinary bladder tumor carcinoma therapy'. For 'neuroendocrine kidney tumor' 570 , for 'neuroendocrine kidney carcinoma' 449, and for 'neuroendocrine kidney tumor carcinoma therapy' 154 papers were found. Only publications in English language were included, and also English language abstracts even if the whole paper was written in another language. Basically, reviews papers were excluded unless they were published after the year 2000, and contained data essential for this review. A comprehensive summary regarding the prognosis and potential therapy in case of urological NETs is presented.

\section{Results}

\section{Neuroendocrine tumors of the kidney}

Neuroendocrine tumors of the kidney are exceedingly rare, and they are classified into well-differentiated tumors, small cell carcinomas and large cell carcinomas (5).

Well-differentiated NET of the kidney. Primary kidney welldifferentiated neuroendocrine tumors (formerly carcinoids) are rare. Only about 90 cases are reported in the literature (6). Interestingly, a significant proportion of kidney NETs were associated with horseshoe kidney (18-26\% of the patients) (7, $8)$. There is no gender predilection. The mean age of the patients was 49 years, and approximately $25-50 \%$ of the cases were discovered accidentally, and the remaining patients presented with symptoms similar to the ones caused by renal cell carcinoma (RCC), such as pain in the pelvic region, weight loss, fever, palpable mass, and hematuria (3). Carcinoid syndrome is infrequent, and it is presented only in $10-15 \%$ of patients with the following symptoms: flush, diarrhea, and generalized edema (9). Radiologically, neither the CT nor the MRI scan can distinguish this tumor from renal cell carcinoma. Somatostatin receptor scintigraphy with octreotide has a high sensitivity for the small and clinically silent renal NETs, and it also has an important role in staging, follow-up, and surveillance of the disease $(9,10)$. Macroscopically, welldifferentiated renal tumors are solitary and well-circumscribed, occasionally with a pseudocapsule. Focal hemorrhage, calcification, cystic changes, and tumor cell necrosis are uncommon (11). The histogenesis of renal NETs are yet unknown. The renal pelvis contains neuroendocrine cells, but not the renal parenchyma. The most popular and acceptable hypothesis is that renal NETs differentiate from neuroendocrine-committed, primitive totipotential cell lines (12). Histologically, polygonal tumor cells with granular amphophilic to eosinophilic cytoplasm can be observed forming vascularized trabeculae or nests. The nuclei are ovalshaped with the typical "salt and pepper" chromatin and minimal pleiomorphism (13). Immunohistochemically, these tumors demonstrate diffuse chromogranin A, synaptophysin, CD56, and cytokeratin labeling $(12,13)$. In support, no admixture of renal NET and clear cell RCC within the same tumor has been documented; only one case of synchronous renal NET and contralateral multilocular cystic renal neoplasm of low malignant potential has been recorded (12). The prognosis is controversial; some patients survive for only 6 months, some others for many years, even with metastases (14). Renal NET is a slow-growing tumor; patients show a prolonged clinical course, even when they have a metastatic disease that indicates the indolent behavior of renal NETs (13). The first choice of therapeutic management for the localized and even for the metastatic well-differentiated tumors could be surgical resection $(5,15)$ because these tumors are chemoresistant (12). The prognostic and therapeutic details are presented Table II $(10,13,16-19)$.

Small cell neuroendocrine carcinoma of the kidney. Renal small cell neuroendocrine carcinomas (SCNEC) are rare, the approximate number of the reported cases is $50(6,20-22)$. These tumors resemble the small cell carcinoma of the lungs. In renal small cell neuroendocrine carcinoma, the mean age of the patients is 59 years; there is no gender predilection, and the left to right side ratio is $1: 1.5$. The clinical symptoms are abdominal pain, macroscopic hematuria, and weight loss. Macroscopically, these are large tumors with a range from 100$230 \mathrm{~mm}$, and usually infiltrate the entire kidney (20). The cut surface is soft, whitish, gritty, and necrotic with a solid growth. Infiltration of the renal sinus, renal vein, and perirenal tissue is frequent (21). Microscopically, the tumor consists of poorly differentiated small, round cells that compose sheets and nests. Mitoses, vascular tumor emboli, and extensive necrosis are common (13). The tumor cells show dot-like cytoplasm 
Pósfai et al: Neuroendocrine Neoplasms of the Genitourinary Tract (Review)

Table II. Neuroendocrine tumors of the kidney: prognostic and therapeutic data from current references.

\begin{tabular}{|c|c|c|c|c|}
\hline & Prognosis & References & Potential therapy & References \\
\hline \multicolumn{5}{|l|}{ Kidney } \\
\hline \multirow[t]{3}{*}{ Well-diff. NET } & Indolent behavior in horseshoe kidney & $\begin{array}{l}\text { Motta et al. } \\
2004 \text { (16) }\end{array}$ & $\begin{array}{l}\text { Ovarian and hepatic metastases, one year } \\
\text { after thecomplete surgery (hysterectomy, } \\
\text { nephrectomy, hepatectomy) no recurrence }\end{array}$ & $\begin{array}{c}\text { Gedaly et al. } \\
2008 \text { (17) }\end{array}$ \\
\hline & $\begin{array}{l}45 \% \text { of cases present with perirenal fat } \\
\text { and renal vein infiltration, in } 50-60 \% \text { of } \\
\text { patients occured paraaortic lymph node, } \\
\text { lung, liver and bone metastases }\end{array}$ & $\begin{array}{l}\text { Romero et al. } \\
2006 \text { (10) }\end{array}$ & $\begin{array}{l}\text { Sunitinib in vascular endothelial growth } \\
\text { factor and hypoxia-inducible } \\
\text { factor } 2 \text { positive cases }\end{array}$ & $\begin{array}{l}\text { Finley et al. } \\
2011 \text { (18) }\end{array}$ \\
\hline & $\begin{array}{c}\text { High metastatic rate: age }>40 \text { years, } \\
\text { tumors }>4 \mathrm{~cm}, \mathrm{~T} 3 \text { stage, } \\
\text { mitotic rate }>1 / 10 \mathrm{HPF}\end{array}$ & $\begin{array}{l}\text { Mazzucchelli } \\
\text { et al. } \\
2009 \text { (13) }\end{array}$ & $\begin{array}{l}\text { OS was } 9 \text { months after radical } \\
\text { nephrectomy, no local } \\
\text { recurrence, no metastasis }\end{array}$ & $\begin{array}{l}\text { Inagaki et al. } \\
2013 \text { (19) }\end{array}$ \\
\hline \multirow[t]{4}{*}{ SCNEC and LCNEC } & $\begin{array}{c}75 \% \text { of the patients died } \\
\text { within one year }\end{array}$ & $\begin{array}{l}\text { Lane et al. } \\
2007 \text { (6) }\end{array}$ & $\begin{array}{l}\text { Small cell neuroendocrine } \\
\text { carcinoma occured } 4 \text { years after } \\
\text { surgery with local recurrence }\end{array}$ & $\begin{array}{l}\text { Piedra Lara } \\
\quad \text { et al. } \\
2003 \text { (29) }\end{array}$ \\
\hline & $\begin{array}{l}\text { Poor prognosis, survival is less than } \\
1 \text { year, with frequent extrarenal } \\
\text { extension, regional lymph } \\
\text { node, brain, bone, adrenal } \\
\text { gland and liver metastases }\end{array}$ & $\begin{array}{l}\text { Mazzucchelli } \\
\text { et al. } \\
2009 \text { (13) } \\
\text { Kuroda } \text { et al. } \\
2014 \text { (24) }\end{array}$ & $\begin{array}{l}\text { Platinum-based chemotherapy } \\
\text { for treatment or palliation }\end{array}$ & $\begin{array}{l}\text { Lane et al. } \\
2007 \text { (6) }\end{array}$ \\
\hline & $\begin{array}{l}\text { One case occured in kidney } \\
\text { transplant recipient }\end{array}$ & $\begin{array}{l}\text { Mohd et al. } \\
2016(28)\end{array}$ & $\begin{array}{l}\text { Surgery in case of tumor } \\
\text { thrombus, } 7 \text { months OS }\end{array}$ & $\begin{array}{l}\text { Xu et al. } \\
2009(30)\end{array}$ \\
\hline & $\begin{array}{l}\text { One case with pulmonary, pancreatic } \\
\text { and cardiac metastases }\end{array}$ & $\begin{array}{l}\text { Shimbori et al. } \\
2017 \text { (27) }\end{array}$ & $\begin{array}{l}\text { Surgery plus chemotherapy, } \\
17.3 \text { months overall survival } \\
\text { Surgery, platinum-based } \\
\text { chemotherapy and radiotherapy }\end{array}$ & $\begin{array}{l}\text { Teegavarapu } \\
\text { et al. } 2014(31) \\
\text { Shimbori et al. } \\
2017 \text { (27) }\end{array}$ \\
\hline
\end{tabular}

OS: Overall survival.

staining with cytokeratin, and they are variably positive for chromogranin A, synaptopthysin, CD56, and NSE. As seen in the bladder, primary renal SCNEC can coexist with in situ and/or papillary urothelial carcinoma, squamous cell carcinoma, or adenocarcinoma (23). They are highly aggressive tumors, and they are associated with poor prognosis; the median survival is less than 1 year $(13,24)$.

Large cell neuroendocrine carcinoma of the kidney. Renal large cell neuroendocrine carcinoma (LCNEC) is an extremely rare form of cancer with fewer than 10 cases in the literature $(2,6,25-27)$. There is no gender predilection, and the peak age of incidence is between 50 and 60 years. Most patients present in an advanced stage; the main symptoms and signs are pain in the flank, palpable mass, hydronephrosis, and hematuria, and in some cases, the symptoms and signs are induced by the distant metastases (2). Grossly, renal LCNECs have a solid cut surface with necrosis, and the extrarenal extension is common $(2,25)$. The tumor cells are large with abundant cytoplasm, vesicular chromatin, and prominent nucleoli. There is a brisk mitotic rate, usually more than 10 per high power field (2). For establishing the diagnosis, at least focal positivity of the NE markers is essential (6). The diagnosis can be mistaken for high-grade renal cell carcinoma or urothelial carcinoma. The clinical prognosis of these carcinomas is very poor (2). There is no indication of systematic therapy for renal SCNEC and LCNEC. Surgery, platinum-based chemotherapy, and radiotherapy could be an effective multimodal management (27). See Table II for particular prognostic and therapeutic data about SCNEC and $\operatorname{LCNEC}(6,13,24,27-31)$.

\section{Neuroendocrine tumors of the urinary bladder}

Neuroendocrine tumors are very rare in this site, and they can be classified as well-differentiated tumors, SCNEC, and LCNEC.

Well-differentiated neuroendocrine tumors of the urinary bladder. Well-differentiated neuroendocrine tumors of the urinary bladder (previously called carcinoids) are extremely rare; there are, approximately, only 25 reported cases in the literature. These tumors usually develop in elderly male patients (mean age: 56 years). Symptoms of the disease are the following: hematuria and irritating voiding difficulties. No association with carcinoid syndrome has been reported in the literature $(32,33)$. These tumors are usually discovered accidentally (34). Cystoscopy may reveal polypoid structures with submucosal infiltration 3 to $30 \mathrm{~mm}$ 
in size. The tumor is usually localized to the trigone and the neck of the bladder, but there are several cases in the literature in which the prostatic urethra is involved as well (35). According to other theories, the tumor originates from metaplastic bladder urothelium or from transformed neuroendocrine cells, especially in the region of the trigone (12). The exact cellular origin of bladder NET is still unknown; however, it has been postulated that NETs may arise from NE cells of different kind of reactive lesions (36). Microscopic features are similar to NETs located in other organs. Histologically, the tumor cells are cuboidal or columnar with abundant amphophilic cytoplasm, and they are arranged in an insular, acini, trabecular, or pseudoglandular pattern in a vascular stroma with finely stippled chromatin and inconspicuous nucleoli. Mitotic figures are infrequent, and no tumor cell necrosis can be seen. Typically, the tumor cells are found in the lamina propria and are positive for NE markers (chromogranin A, synaptophysin, and CD56) and cytokeratins (23, 34). In addition, prostate-specific acid phosphatase (PAP) expression was detected. No other prostate marker positivity can be detected (36). Due to the lack of long-term follow-up data, the prognosis cannot be exactly estimated.

Small cell neuroendocrine carcinoma of the urinary bladder. $0.5-1 \%$ of all primary bladder malignancies are SCNECs. Its pure form is rare; half of the cases are mixed with urothelial carcinoma, adenocarcinoma, squamous cell carcinoma, and/or sarcomatoid features (37). SCNEC has a slight male predominance with a male-to-female ratio of $3: 1$. The mean age of the patients is 66 years (23). 80\% of the patients have a history of cigarette smoking. Common clinical symptom of this disease is hematuria. Sometimes local irritation, pain in the pelvic region, or urinary obstruction may also occur (38). In most of the cases, macroscopic histological examination reveals large solid, polypoid, or nodular, ulcerated mass with muscle or fat tissue invasion. The fundus, the lateral and posterior walls of the bladder are most commonly involved (39). Macroscopically, SCNEC is not different from urothelial carcinoma. SCNEC usually has a polypoid, solid, or ulcerative appearance with deep invasion of the bladder wall (40). Microscopically, histological features of bladder SCENC are similar to those of small cell carcinoma of the lungs. The tumor is composed of small to intermediate size cells with scanty cytoplasm, inconspicuous nucleoli, and in several cases, the typical salt-and-pepper chromatin can be observed as well (41). Brisk mitotic activity, vascular invasion, and necrosis can also be detected (23). Mitotic count and Ki67 index are important for grading (42). Tumor cells express both epithelial and neuroendocrine markers. Chromogranin A, synaptophysin, neuron-specific enolase, CD57, CD56, protein gene product 9.5, and 'dot-like' cytokeratin positivity are characteristic for this kind of tomur. Chromogranin $\mathrm{A}$ is a specific but quite insensitive marker, which is expressed in $30 \%$ of the tumors. The Ki67 index is variable, and nuclear accumulation of p53 protein can be observed as well (43-45). The use of TTF-1 to differentiate the tumor from pulmonary small cell carcinoma is dubious as $25-39 \%$ of bladder small cell carcinomas also express TTF-1. Several allelic and chromosomal losses, deletions, and gains have already been identified. Some of these affected oncogenes, like $M Y C$ has a high amplification level in SCNEC of the bladder (43). Genetic trials proved p53 and $R B 1$ to be the most frequently altered genes in $90 \%$ of patients with small cell carcinoma. Bladder-specific mutations in the TERT promoter have been reported. These genetic results are more likely to refer to urothelial carcinoma rather than small cell lung cancer (46). Bladder SCNEC has an aggressive clinical course $(23,47)$. CT images of bladder small cell cancer show a heterogeneous broad-based polypoid mass with extensive local invasion (at least T3 or T4 stage) (3). Bladder SCNEC tends to have a better outcome than the small cell carcinoma of prostate (48). Most available treatment options can also be administered in case of small cell carcinoma of the lungs. Early diagnosis of the disease as well as surgery, neoadjuvant, adjuvant, or palliative chemotherapy with or without radiotherapy are the cornerstones of patient care $(13,48-50)$. Details about prognosis and therapy are shown in Table III $(13,23,35,41,42,44,47-60)$.

Large cell neuroendocrine tumor of the urinary bladder. Large cell neuroendocrine tumor (LCNEC) of the bladder is an extremely rare form of cancer with fewer than 25 reported cases (61). The disease mainly develops in elderly male patients (36). Histologically, LCNEC is identical to large cell carcinoma of the lungs. Tumor cells are large with a polygonal shape, low nuclear to cytoplasmic ratio, coarse nuclear chromatin, prominent nucleoli, and frequent mitotic figures $(38,62)$. Admixture of LCNEC and other forms of bladder cancer including urothelial carcinoma, squamous cell carcinoma, adenocarcinoma, and sarcomatoid carcinoma can also be detected (63). The genetic background is unknown due to the rarity of the disease (36). Immunohistochemically, the tumor cells show a strong reaction for cytokeratins (AE1/AE3, CAM5.2) and EMA. The expression of NE markers mainly confirm the diagnosis; however, chromogranin A is expressed more frequently in bladder SCNEC than in LCNEC (62). The prognosis of pure bladder large cell carcinoma is similar to small cell cancer (13). The therapeutic options are presented in Table III $(13,61,63-65)$.

\section{Neuroendocrine tumors of the prostate}

Neuroendocrine differentiation in prostate cancer. Almost all prostate carcinomas (PCA) have focal NE differentiation, but confluent zones with focal NE cells or NE cell clusters $(<50$ cells) can be detected only in $5-10 \%$ of cases. The role and origin of prostatic NE cells are unknown (66). There are some 
Pósfai et al: Neuroendocrine Neoplasms of the Genitourinary Tract (Review)

Table III. Neuroendocrine tumors of the urinary bladder: prognostic and therapeutic data from current references.

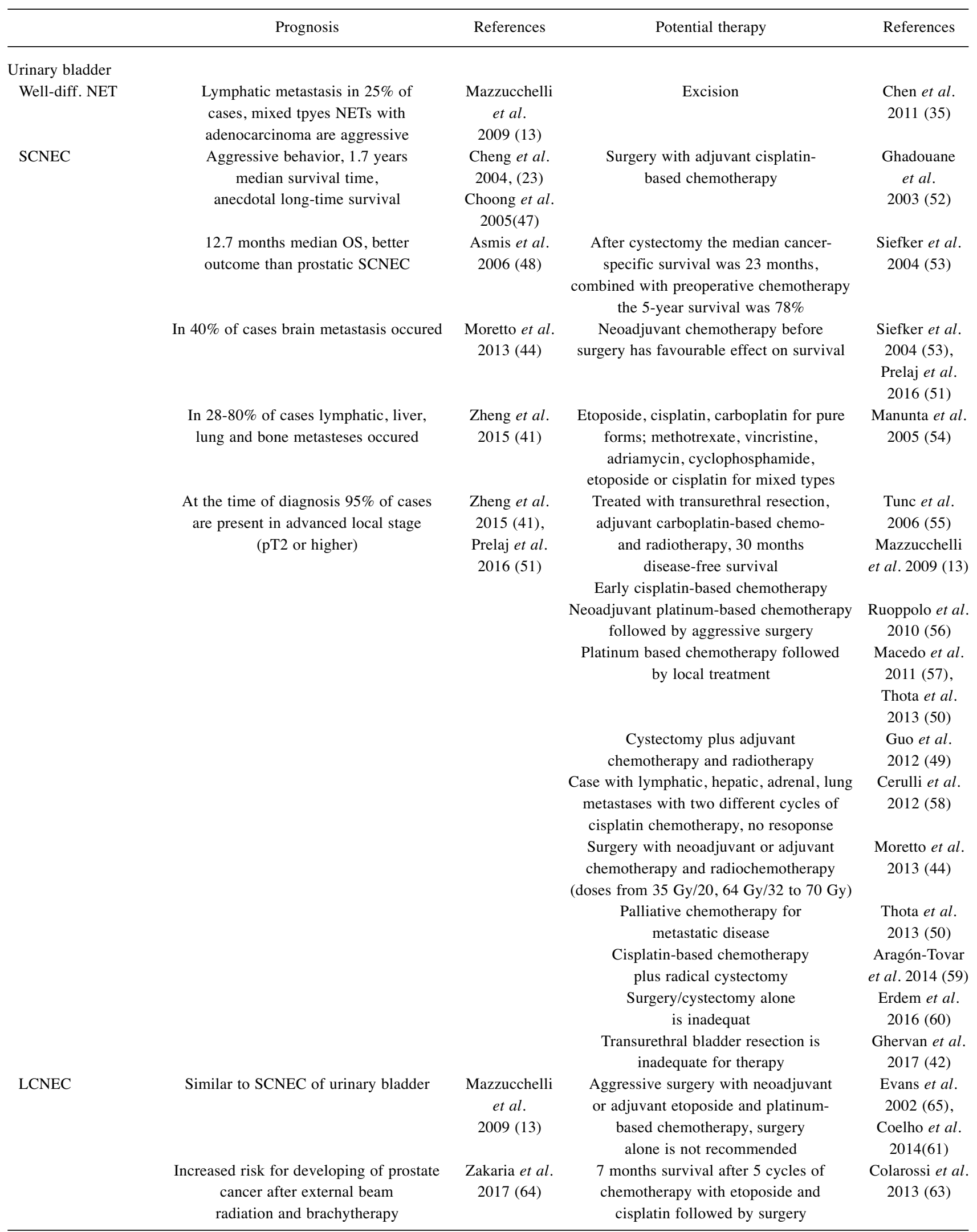


Table IV. Neuroendocrine tumors of the prostate: prognostic and therapeutic data from current references.

\begin{tabular}{|c|c|c|c|c|}
\hline & Prognosis & References & Potential therapy & References \\
\hline \multicolumn{5}{|l|}{ Prostate carcinoma } \\
\hline \multirow[t]{11}{*}{ Adenocc with NED } & $\begin{array}{l}\text { Metastatic androgen-independent } \\
\text { prostate cancer with focal NE } \\
\text { differentiation has poor prognosis }\end{array}$ & $\begin{array}{l}\text { Cheville et al. } \\
2002(75)\end{array}$ & $\begin{array}{l}\text { Aurora A inhibitor in } \\
\text { metastatic castrate-resistant } \\
\text { and neuroendocrine prostate }\end{array}$ & $\begin{array}{l}\text { clinical trial } \\
\quad(77)\end{array}$ \\
\hline & $\begin{array}{l}\text { Serum chromogranin A does not correlate } \\
\text { with response to chemotherapy }\end{array}$ & $\begin{array}{l}\text { Berruti } \text { et al. } \\
2005 \text { (95) }\end{array}$ & $\begin{array}{l}\text { Lanreotide with dexamathasone } \\
\text { with } 7 \text { months PFS }\end{array}$ & $\begin{array}{l}\text { Koutsilieris } \\
\text { et al. } 2001 \text { (96) }\end{array}$ \\
\hline & $\begin{array}{l}\text { No correlation of neuroendocrine } \\
\text { differentiation with clinical outcome }\end{array}$ & $\begin{array}{l}\text { Fine SW } \\
2007(5)\end{array}$ & $\begin{array}{c}\text { Lanreotide with ethinylestradiol } \\
\text { with } 18.5 \text { PFS }\end{array}$ & $\begin{array}{l}\text { Di Silverio } \\
\text { et al. } 2003 \text { (97) }\end{array}$ \\
\hline & $\begin{array}{l}\mathrm{Ki}-67 \text { index as independent } \\
\text { prognostic factor }\end{array}$ & $\begin{array}{l}\text { Komiya et al. } \\
2009(66)\end{array}$ & Serotonin receptor antagonists & $\begin{array}{l}\text { Dizeyi et al. } \\
2005 \text { (79) }\end{array}$ \\
\hline & $\begin{array}{l}\text { AURKA and/or n-MYC amplifications } \\
\text { might be a predictive factor }\end{array}$ & $\begin{array}{l}\text { Beltran } 2011(76), \\
\text { Terry and Beltran } \\
2014(67)\end{array}$ & $\begin{array}{l}\text { Bombesin-like/gastrin-releasing } \\
\text { peptide antagonists in androgen- } \\
\text { independent prostate cancer }\end{array}$ & $\begin{array}{l}\text { Stangelberger } \\
\text { et al. } 2006 \\
\text { (78) }\end{array}$ \\
\hline & & & $\begin{array}{c}\text { Three courses of cisplatin } \\
\text { and irinotecan }\end{array}$ & $\begin{array}{l}\text { Inoue } \text { et al. } \\
2007 \text { (98) }\end{array}$ \\
\hline & & & $\begin{array}{c}\text { mTOR pathway in the } \\
\text { management }\end{array}$ & $\begin{array}{l}\text { Garcia et al. } \\
2008 \text { (99) }\end{array}$ \\
\hline & & & Somatostatin analogs & $\begin{array}{l}\text { Komiya et al. } \\
2009 \text { (66) }\end{array}$ \\
\hline & & & $\begin{array}{l}\text { High doses of paclitaxel and carboplatin } \\
\text { then irradiation }(60+10 \mathrm{~Gy})\end{array}$ & $\begin{array}{c}\text { Maebayashi } \\
\text { et al. } 2015(100)\end{array}$ \\
\hline & & & $\begin{array}{l}\text { Etoposide and carboplatin } \\
\text { then docetaxel only }\end{array}$ & $\begin{array}{l}\text { Wei et al. } \\
2016(101)\end{array}$ \\
\hline & & & $\begin{array}{c}\text { Intracellular chemokine CXCL12 } \gamma \\
\text { as therapeutic target }\end{array}$ & $\begin{array}{l}\text { Jung et al. } \\
2018 \text { (102) }\end{array}$ \\
\hline Well-diff. NET & Relatively indolent and favorable & $\begin{array}{l}\text { Mazzucchelli } \\
\text { et al. } 2009 \text { (13) }\end{array}$ & $\begin{array}{c}\text { Neoadjuvant chemotherapy } \\
\text { and radical prostatectomy for } \\
\text { metastatic well-differentiated NETs }\end{array}$ & $\begin{array}{l}\text { Tash } \text { et al. } \\
2002 \text { (82) }\end{array}$ \\
\hline \multirow[t]{8}{*}{ SCNEC } & $\begin{array}{l}\text { Testicle metastasis } 2.5 \text { years after } \\
\text { androgen deprivation therapy }\end{array}$ & $\begin{array}{l}\text { Schneider } \\
\text { et al. } 2006(103)\end{array}$ & $\begin{array}{l}\text { Cisplatin-based chemotherapy plus } \\
\text { radiotherapy failed to improve the } \\
\text { survival, patient died after } 4 \text { months }\end{array}$ & $\begin{array}{c}\text { Benchenkroun } \\
\text { et al. } \\
2002(104), \\
\text { Stein } \text { et al. } \\
2008(105)\end{array}$ \\
\hline & $\begin{array}{l}\text { No difference in prognosis between pure } \\
\text { small cell and mixed with adenocarcinoma }\end{array}$ & $\begin{array}{l}\text { Mazzucchelli } \\
\text { et al. } 2009 \text { (13) }\end{array}$ & Octreotide therapy recived remission & $\begin{array}{l}\text { Spieth et al. } \\
2002(106)\end{array}$ \\
\hline & $\begin{array}{l}\text { Small cell component usually means } \\
\text { a terminal phase }\end{array}$ & $\begin{array}{l}\text { Mazzucchelli } \\
\text { et al. } 2009 \text { (13) }\end{array}$ & $\begin{array}{c}\text { Combination of doxorubicin, } \\
\text { etoposide and cisplatin resulted } \\
5.8 \text { months PFS and } 10.5 \text { months OS }\end{array}$ & $\begin{array}{l}\text { Papandreou } \\
\text { et al. } 2002 \\
\quad(107)\end{array}$ \\
\hline & $\begin{array}{l}\text { Aggressive behavior, poor prognosis with } \\
19 \text { months median cancer-specific } \\
\text { survival, } 2 \text {-year and 5-year survival } \\
\text { were } 14.3 \%, 27.5 \% \text { respectively }\end{array}$ & $\begin{array}{l}\text { Deorah et al. } \\
2012(93)\end{array}$ & $\begin{array}{l}\text { Metronomic cyclophosphamide } \\
\text { and mitoxantrone have favorable effect }\end{array}$ & $\begin{array}{l}\text { Berry et al. } \\
2002(108) \text {, } \\
\text { Lord } \text { et al. } \\
2007 \text { (109) }\end{array}$ \\
\hline & & & $\begin{array}{l}\text { Cisplatin plus etoposide, progression } \\
\text { controlling for } 7 \text { months }\end{array}$ & $\begin{array}{l}\text { Yashi et al. } \\
2006(110)\end{array}$ \\
\hline & & & $\begin{array}{l}\text { Four cycles of irinotecan plus cisplatin, } \\
\text { after second cycle neuron-specific enolase } \\
\text { level was normalized and after the } \\
\text { fourth cycle was complete remission }\end{array}$ & $\begin{array}{l}\text { Komiya et al. } \\
2009 \text { (66) }\end{array}$ \\
\hline & & & $\begin{array}{c}\text { Three course intra-arterial infusion of } \\
\text { cisplatin plus ifosfamid, then external } \\
\text { beam radiaton }\end{array}$ & $\begin{array}{l}\text { Uemura et al. } \\
2013 \text { (111) }\end{array}$ \\
\hline & & & $\begin{array}{l}\text { Carboplatin plus docetaxel followed by } \\
\text { cisplatin plus etoposide, objective response } \\
\text { rate } 33 \% \text {, median survival } 16 \text { months }\end{array}$ & $\begin{array}{l}\text { Aparicio et al. } \\
2013 \text { (112) }\end{array}$ \\
\hline
\end{tabular}




\begin{tabular}{|c|c|c|c|c|}
\hline & Prognosis & References & Potential therapy & References \\
\hline \multirow{15}{*}{ LCNEC } & \multirow{15}{*}{ Rapid course, poor prognosis } & \multirow{15}{*}{$\begin{array}{c}\text { Evans } \text { et al. } \\
2006 \text { (95) }\end{array}$} & $\begin{array}{l}\text { Combination of carboplatin, etoposide, } \\
\text { cyclophosphamide, doxorubicin and } \\
\text { vincristine between } 4 \text { and } 8 \text { cycles and } \\
\text { then locoregional methods }\end{array}$ & $\begin{array}{l}\text { Aparicio et al. } \\
2014 \text { (113) }\end{array}$ \\
\hline & & & $\begin{array}{l}\text { Systemic chemotherapy alone or combintion } \\
\text { with androgen deprivation therapy }\end{array}$ & $\begin{array}{c}\text { Parimi et al. } \\
2014 \text { (73) }\end{array}$ \\
\hline & & & $\begin{array}{l}\text { For advanced stage disease is } \\
\text { platinum-based chemotherapy }\end{array}$ & $\begin{array}{l}\text { Campedel et al. } \\
\quad 2017 \text { (94) }\end{array}$ \\
\hline & & & Case report with paraneoplastic syndrome & Peverelli \\
\hline & & & of inappropriate antidiuretic hormone secretion & et al. \\
\hline & & & and high sensitivity for chemotherapy & 2017 (114) \\
\hline & & & $\begin{array}{l}\text { Platinum-based chemotherapy, but } \\
\text { response duration is short }\end{array}$ & $\begin{array}{l}\text { Akamatsu et al. } \\
2018(115)\end{array}$ \\
\hline & & & $\begin{array}{l}\text { Platinum based chemotherapy } \\
\text { with } 7 \text { months survival }\end{array}$ & $\begin{array}{l}\text { Evans et al. } \\
2006 \text { (95) }\end{array}$ \\
\hline & & & Neoadjuvant chemotherapy (taxol, & Okoye et al. \\
\hline & & & vepesid and cisplatin) with & $2013(116)$ \\
\hline & & & Lupron followed by radical & \\
\hline & & & prostatectomy and pelvic & \\
\hline & & & lymphadenectomy with & \\
\hline & & & 13 months survival & \\
\hline & & & Effects of icaritin in mice model & Sun et al. \\
\hline
\end{tabular}

OS: Overall survival; PFS: progression-free survival.

potential theories about the origin of NE cells: (1) NE and conventional adenocarcinoma components may arise from one tumor clone with stem cell-like abilities (i.e., epithelial and NE differentiation) (67); (2) NE tumor cells may evolve from adenocarcinoma cells by genetic alterations, due to treatment interventions (i.e., androgen deprivation therapy, radiation and chemotherapy) or changes in the microenvironment of the tumor cells (i.e., hypoxia, cytokines, or hormones); (3) malignant NE phenotype arises from normal prostatic NE cells (67). Reduced activity and/or expression of the androgen receptor (AR) can be observed in NE cells, resulting in a hormone-insensitive cellular population embedded in the tumor, which may lead to the progression of the disease (6769). NE cells are indistinguishable from tumor cell in PCA; therefore, the identification is based on the expression of $\mathrm{NE}$ markers: chromogranin A, serotonin, and somatostatin. Prostate-specific markers (prostate specific antigen - PSA, prostatic acid phosphatase - PAP) positivity can also be found in case of NE cells (5). There is a relationship between the elevated proportion of NE differentiation in castrate-resistant prostate cancer and high serum level of chromogranin A. It could be an indicator in patients without elevated serum PSA level $(70,71)$. Some data show that more than $50 \%$ of all neuroendocrine prostatic carcinoma cases are associated with prostatic adenocarcinomas and clinically with androgenreceptor independence. Therefore, in 2013, the Prostate Cancer Foundation Working Committee on neuroendocrine PCA suggested the terminology of "AR-negative prostate cancer" for neuroendocrine prostatic carcinoma. However, mixed tumors contain AR-positive and also AR-negative cells, and in rare cases, hybrid tumors can be identified where neuroendocrine markers and AR are expressed in the same tumor cells (72). Studies have proven that prolonged androgen deprivation in androgen sensitive metastatic and also in primary PCA results in increased neuroendocrine differentiation (73). Focal NE differentiation develops in $10 \%$ to $100 \%$ of prostate adenocarcinomas treated by anrogene deprivation therapy (ADT), especially in advanced stage but with relatively low serum PSA (74). The prognosis is controversial (5), but in fact, prostate cancer with focal NE differentiation has poor prognosis $(13,75)$. In order to better understand the importance of NE differentiation, the molecular mechanisms also have to be studied. Recently, two protooncogenes have become the center of attention, namely, cytoplasmic serine/threonine-protein kinase AURKA (Aurora kinase $A$ ) and nuclear transcription factor n-MYC, which might be responsible for the malignant NE phenotype in prostate cancers (76). Terry and Beltran have found in their 
study that the inhibition of AURKA blocks the growth of NE cells in vitro and in vivo. Detection of AURKA may lead to further therapeutic options (77). Prostatic neuroendocrine tumors are treated with combined somatostatin analogs that have a high therapeutic index (66). Bombesin/GRP antagonists and serotonin antagonists may be regarded as further therapeutic options $(78,79)$. Castration-resistant prostate cancer is usually fatal, and successful management is still a problem. Nelson et al. have proposed a theory about four different stages of so-called adaptation in prostate cancer on the basis of androgenic ligands and the activity of AR (80).

Well-differentiated neuroendocrine tumor of the prostate. Welldifferentiated neuroendocrine tumors of the prostate are extremely rare; only a few cases of them have been reported $(81,82)$. No specific age group in which prostatic NET develops more frequently can be identified; nevertheless, some authors suggest that it is usually found accidentally in elderly patients, while others report that locally advanced and metastatic diseases are more frequent in younger adults (13, 73). Clinical symptoms are hematuria, burning nocturia, frequent urination, and different symptoms of urinary retention. Macroscopically, the size of the tumor is variable, and sometimes infiltrates the entire prostate. For the diagnosis of pure NET, conventional PCA with NE differentiation need to be excluded, which could be challenging (5). Histological features are similar to NETs of other organs: trabecular, insular, mixed architectural patterns of generally polygonal or spindleshaped cells, with low-grade cytological features and "salt and pepper" chromatin. The cytoplasm is abundant and eosinophilic, and mitotic figures are uncommon $(81,83)$. The cells are positive for chromogranin A and synaptophysin, and negative for PSA and PAP. If a tumor represents nested architecture and uniform nuclei with positive staining for PSA and NE markers, a "NET-like" PCA should be considered (73, 74). The prognosis is hard to define because of their rarity, but nowadays, it is considered to be favorable (13).

Small cell neuroendocrine carcinoma of the prostate. Prostatic SCNEC represents approximately $1-5 \%$ of all prostate malignancies (5). Local symptoms are similar to those represented in case of conventional PCA, but in a few cases, paraneoplastic syndrome develops, such as Cushing syndrome, hypercalcemia, syndrome of inappropriate antidiuretic hormone secretion, and Eaton-Lambert syndrome (84-86). The serum PSA concentration is variable (87). Prostatic SCNEC may develop in a pure form or can be mixed with acinar PCA $(13,73)$. At least $25 \%$ of patients with advanced PCA may eventually develop SCNEC. The number of NE differentiation in PCA may increase because of the novel AR targeted therapies for castration-resistance PCA (88). Microscopically, SCNEC has similar histological features to small cell carcinoma in other organs with minimal cytoplasm, indistinct cell borders, nuclear molding, extensive tumor cell necrosis, high mitotic rate, and nuclear fragility (73). Approximately 50\% of the cases express TTF1, hence the use of TTF-1 expression cannot distinguish between primary prostatic SCNEC and metastatic small cell carcinoma of other organs (73). Chromogranin and synaptophysin staining is intense in $90 \%$ and $17 \%$ of cases, respectively (5). $24 \%$ of cases are diffusely positive for PSA and PAP, which suggests that there is a link between acinar PCA and prostatic SCNEC (89-91). In the diagnostic process, fluorescence in situ hybridization (FISH) or reverse transcription polymerase chain reaction may be useful in order to detect a gene fusion between the ETS family member gene ERG and TMPRSS 2 gene. Half of the prostatic small cell cases are positive for TMPRSS2-ERG gene fusion by FISH (92). Grading of small cell cancer should not be done according to the Gleason system, although some pathologists still give Gleason score with an additional comment (13). Prostatic SCNEC has one of the most aggressive behaviors of all prostate cancers, often in advanced local stage (93). Small cell carcinomas of the prostate are thought to be identical to small cell carcinomas of the lungs. Therefore, cytotoxic agents given in case of small cell carcinoma of the lungs can be usually administered to patients with small cell carcinoma of the prostate as well (94), but there are also other therapeutic options available.

Large cell neuroendocrine carcinoma of the prostate. Few cases of LCNEC have been reported $(5,95)$. Histologically, it shows similar features to the ones seen in other organs. Typically, the tumor cells have abundant amphophilic cytoplasm and large nuclei with coarse chromatin and prominent nucleoli. Brisk mitotic activity and geographic necrosis can be noticed as well. The tumor cells are larger than the cells of small cell carcinoma or conventional prostatic adenocarcinoma (73). However, it is difficult to distinguish LCNEC from Gleason $5+5$ PCA, hence the chance of a misdiagnosis is quite high (95). Immunohistochemically, these tumors are strongly positive for chromogranin A, synaptophysin, CD56, CD57, and P504S/ $\alpha$-methylacyl CoA racemase. A focally positive staining pattern can be identified for PSA and PAP in LCNEC, and they are negative for androgen receptor. Their prognosis is poor, and they are frequently present with distant metastases at the time of their discovery. They might be treated with long-term hormone therapy (95). Table IV contains further prognostic and therapeutic details for all prostatic neuroendocrine tumors (5, $13,66,67,73,75-79,82,93-117)$.

\section{Discussion}

As a result of the rarity of these tumors, there is a diagnostic challenge and therapeutic dilemma. To distinguish between a NET and an undifferentiated tumor of the GU tract can become an exceedingly problematic task, and that is why special 
immunohistochemichal stainings, beyond the standard markers, should be ordered in such cases. NE markers have good specificity although their sensitivity is different. Since neuroendicrine tumors are more common in the lungs and the gut than in the GU tract, the possibility of a metastatic involvement from these sites should be considered first. Because the pathologist has limited options, the exclusion of a metastasis in other organs is mainly based on the clinical parameters. The outcome of these tumors is poor; therefore, an exact histological and immunohistochemical verification is needed to prevent misdiagnosis. No guidelines are available regarding the optimum management; thus, different treatment strategies are applied to improve the poor prognosis of the disease. The therapy of renal and bladder NET is based on the management of NET in other sites. There are some important approaches for the management of prostatic NET. Prostatic NETs are mainly AR negative. Data show that advanced prostatic cancer often presents with mixed histological features, with AR-dependent and AR-independent tumor cells; moreover, hybrid tumors can also be detected with both NE markers and AR expressing tumor cells. Neuroendocrine differentiation in prostatic adenocarcinoma characteristically occurs in ARindependent/castrate-resistant prostate cancers. The therapeutic options involve chemotherapy, somatostatin analogs, and bombesin-like antagonists. Somatostatin analogs are the basic therapeutic regimens in case of well-differentiated NETs.

\section{References}

1 Strosberg JR, Coppola D, Klimstra DS, Phan AT, Kulke MH, Wiseman GA and Kvols LK: The NANETS Consensus Guidelines for the Diagnosis and Management of Poorly Differentiated (High-Grade) Extrapulmonary Neuroendocrine Carcinomas. Pancreas 39(6): 799-800, 2010.

2 Lane BR, Jour G and Zhou M: Renal neuroendocrine tumors. Indian J Urol 25(2): 155-160, 2009.

3 Katabathina VS, Vikram R, Olaoya A, Paspulati RM, Nicolas MM, Rao P, Zaheer A and Prasad SR: Neuroendocrine neoplasms of the genitourinary tract in adults: cross-sectional imaging spectrum. Abdom Radiol 42: 1472-1484, 2017.

4 Moch H, Humphrey PA, Ulbright TM and Reuter VE: WHO Classification of Tumours of the Urinary System and Male Genital Organs. Fourth edition. IARC WHO Classification of Tumours, No 8, 2016.

5 Fine SW: Neuroendocrine lesions of the genitourinary tract. Adv Anat Pathol 14(4): 286-296, 2007.

6 Lane BR, Chery F, Jour G, Sercia L, Magi-Galluzzi C, Novick $\mathrm{AC}$ and Zhou M: Renal neuroendocrine tumours: a clinicopathological study. BJU Int 100(5): 1030-1035, 2007.

7 Mardi K, Negi L and Srivastava S: Well differentiated neuroendocrine tumor of the kidney: Report of a rare case with review of literature. Indian J Pathol Microbiol 60(1): 105-107, 2017.

8 Omiyale AO and Venyo AK: Primary carcinoid tumour of the kidney: a review of the literature. Adv Urol 2013: 579396, 2013.

9 Eble JN, Sauter G, Epstein JI, Sesterhenn IA (eds.).: World Health Organization classification of tumours: pathology and genetics of tumours of the urinary system and male genital organs. Lyon, IARC, 2004.

10 Romero FR, Rais-Bahrami S, Permpongkosol S, Fine SW, Kohanim S and Jarrett TW: Primary carcinoid tumors of the kidney. J Urol 176: 2359-2366, 2006.

11 Hansel DE, Epstein JI, Berbescu E, Fine SW, Young RH and Cheville JC: Renal carcinoid tumor: a clinicopathologic study of 21 cases. Am J Surg Pathol 31(10): 1539-1544, 2007.

12 Murali R, Kneale K, Lalak N and Delprado W: Carcinoid Tumors of the Urinary Tract and Prostate. Arch Pathol Lab Med 130: 1693-1706, 2006.

13 Mazzucchelli R, Morichetti D, Lopez-Beltran A, Cheng L, Scarpelli M, Kirkali Z and Montironi R: Neuroendocrine tumours of the urinary system and male genital organs: clinical significance. BJU INTERNATIONAL 103: 1464-1470, 2009.

14 Quinchon JF, Aubert S, Biserte J, Lemaitre L, Gosselin B and Leroy X: Primary atypical carcinoid of the kidney: a classification is needed. Pathology 35(4): 353-355, 2003.

15 Kubota Y, Seike K, Maeda S and Tashiro K: Case of primary renal carcinoid tumor with hemorrhage. Hinyokika Kiyo 56(4): 225-228, 2010.

16 Motta L, Candiano G and Pepe P: Neuroendocrine tumor in a horseshoe kidney. Case report and updated follow-up of cases reported in the literature. Urol Int 73(4): 361-364, 2004.

17 Gedaly R, Jeon H, Johnston TD, McHugh PP, Rowland RG and Ranjan D: Surgical treatment of a rare primary renal carcinoid tumor with liver metastasis. World J Surg Oncol 6: 41, 2008.

18 Finley DS, Narula N, Valera VA, Merino MJ, Fruehauf J, Wu ML, Linehan WM and Clayman RV: Immunohistochemical basis for adjuvant anti-angiogenic targeted therapy for renal carcinoid: initial case report. Urol Oncol 29(1): 85-89, 2011.

19 Inagaki Y, Fujita K, Nakai Y, Takayama H, Tsujimura A and Nonomura N: Renal neuroendocrine tumor (carcinoid) : a case report. Hinyokika Kiyo 59(11): 723-727, 2013.

20 Gonzalez-Lois C, Madero S, Redondo P, Alonso I, Salas A and Angeles Montalbán M: Small cell carcinoma of the kidney: a case report and review of the literature. Arch Pathol Lab Med 125: 796-798, 2001.

21 Akkaya BK, Mustafa U, Esin O, Turker K and Gulten K: Primary small cell carcinoma of the kidney. Urol Oncol 21: 1113, 2003.

22 Si Q, Dancer J, Stanton ML, Tamboli P, Ro JY, Czerniak BA, Shen SS and Guo CC: Small cell carcinoma of the kidney: a clinicopathologic study of 14 cases. Hum Pathol 42: 1792-1798, 2011.

23 Cheng L, Pan CX, Yang XJ, Lopez-Beltran A, MacLennan GT, Lin H, Kuzel TM, Papavero V, Tretiakova M, Nigro K, Koch MO and Eble JN : Small cell carcinoma of the urinary bladder: a clinicopathologic analysis of 64 patients. Cancer 101: 957962, 2004.

24 Kuroda N, Imamura Y and Hamashima T: Review of small cell carcinoma of the kidney with focus on clinical and pathobiological aspects. Pol J Pathol 65(1): 15-19, 2014.

25 Palumbo C, Talso M, Dell'Orto PG, Cozzi G, De Lorenzis E, Conti A, Maggioni M, Cesare Rocco BM, Maggioni A and Rocco F: Primary large cell neuroendocrine carcinoma of the renal pelvis: a case report. Urologia 81: 57-59, 2014.

26 Wann C, John NT and Kumar RM: Primary renal large cell neuroendocrine carcinoma in a young man. J Clin Diagn Res 8: ND08-9, 2014. 
27 Shimbori M, Osaka $\mathrm{K}$ and Kawahara T: Large cell neuroendocrine carcinoma of the kidney with cardiac metastasis: a case report. J Med Case Rep 11(1): 297, 2017.

28 Mohd KA, Draman CR, Seman MR, Kalavathy R and Mubarak MY: Metastatic neuroendocrine tumor of small cell type in a kidney transplant recipient. Saudi J Kidney Dis Transpl 27(4): 787-790, 2016.

29 Piedra Lara JD, Tejido Sánchez A, García de la Torre JP, Capitán Manjón C, Cruceyra Betriu G and Leiva Galvis O: Neuroendocrine renal carcinoma. Presentation of a case. Arch Esp Urol 56(2): 178-181, 2003.

$30 \mathrm{Xu} \mathrm{G}$, Chen J and Zhang Z: Primary small cell carcinoma of the kidney with tumour thrombus extension into the inferior vena cava and pulmonary artery: a case report and review of the literature. J Int Med Res 37(2): 587-593, 2009.

31 Teegavarapu PS, Rao P, Matrana M, Cauley DH, Wood CG and Tannir NM: Neuroendocrine tumors of the kidney: a single institution experience. Clin Genitourin Cancer 12(6): 422-427, 2014.

32 Martignoni G and Eble JN: Carcinoid tumors of the urinary bladder: immunohistochemical study of 2 cases and review of the literature. Arch Pathol Lab Med 127: e22-24, 2003.

33 Baydar DE and Tasar C: Carcinoid tumor in the urinary bladder: unreported features. Am J Surg Pathol 35: 1754-1757, 2011.

34 Sugihara A, Kajio K, Yoshimoto T, Tsujimura T, Iwasaki T, Yamada N, Terada N, Tsuji M, Nojima M, Yabumoto H, Mori $\mathrm{Y}$ and Shima $\mathrm{H}$ : Primary carcinoid tumor of the urinary bladder. Int Urol Nephrol 33(1): 53-57, 2002.

35 Chen YB and Epstein JI: Primary carcinoid tumors of the urinary bladder and prostatic urethra: a clinicopathologic study of 6 cases. Am J Surg Pathol 35: 442-446, 2011

36 Kouba $\mathrm{E}$ and Cheng L: Neuroendocrine tumors of the urinary bladder according to the 2016 World Health Organization Classification: Molecular and clinical characteristics. Endocr Pathol 27(3): 188-199, 2016.

37 Trias I, Algaba F, Condom E, Español I, Seguí J, Orsola I, Villavicencio H and García Del Muro X: Small cell carcinoma of the urinary bladder. Presentation of 23 cases and review of 134 published cases. Eur Urol 39(1): 85-90, 2001.

38 Bertaccini A, Marchiori D, Cricca A, Garofalo M, Giovannini C, Manferrari F, Gerace TG, Pernetti R and Martorana G: Neuroendocrine carcinoma of the urinary bladder: case report and review of the literature. Anticancer Res 28(2B): 1369-1372, 2008.

39 Mukesh M, Cook N, Hollingdale AE, Ainsworth NL and Russell SG: Small cell carcinoma of the urinary bladder: a 15year retrospective review of treatment and survival in the Anglian Cancer Network. BJU Int 103(6): 747-752, 2009.

40 Wang X, MacLennan GT, Lopez Beltran A and Cheng L: Small cell carcinoma of the urinary bladder: histogenesis, genetics, diagnosis, biomarkers, treatment, and prognosis. Appl Immunohistochem Mol Morphol 15: 8-18, 2007.

41 Zheng X, Liu D, Fallon JT and Zhong M: Distinct genetic alterations in small cell carcinoma from different anatomic sites. Exp Hematol Oncol 4: 2, 2015.

42 Ghervan L, Zaharie A, Ene B and Elec FI: Small-cell carcinoma of the urinary bladder: where do we stand? Clujul Med 90(1): 13-17, 2017.

43 Church DN and Bahl A: Small cell carcinoma of the bladder. Cancer Treat Rev 32(8): 588-593, 2006.
44 Moretto P, Wood L, Emmenegger U, Blais N, Mukherjee SD, Winquist E, Belanger EC, Macrae R, Balogh A, Cagiannos I, Kassouf W, Black P, Czaykowski P, Gingerich J, North S, Ernst S, Richter S, Sridhar S, Reaume MN, Soulieres D, Eisen A and Canil CM: Management of small cell carcinoma of the bladder: Consensus guidelines from the Canadian Association of Genitourinary Medical Oncologists (CAGMO). Can Urol Assoc J 7(1-2): E44-56, 2013.

45 Zhou H, Liu L, Yu G, Qu GM, Gong PY, Yu X and Yang P: Analysis of clinicopathological features and prognostic factors in 39 cases of bladder neuroendocrine carcinoma. Anticancer Res 37(8): 4529-4537, 2017.

46 Chang MT, Penson AV, Desai NB, Socci ND, Shen R, Seshan VE, Kundra R, Abeshouse A, Viale A, Cha EK, Hao X, Reuter VE, Rudin CM, Bochner BH, Rosenberg JE, Bajorin DF, Schultz N, Berger MF, Iyer G, Solit DB, Al-Ahmadie HA and Taylor BS: Small cell carcinomas of the bladder and lung are characterized by a convergent but distinct pathogenesis. Clin Cancer Res 24(8): 1965-1973, 2018.

47 Choong NW, Quevedo JF and Kaur JS: Small cell carcinoma of the urinary bladder. The Mayo Clinic experience. Cancer 103(6): 1172-1178, 2005.

48 Asmis TR, Reaume MN, Dahrouge $\mathrm{S}$ and Malone S: Genitourinary small cell carcinoma: a retrospective review of treatment and survival patterns at The Ottawa Hospital Regional Cancer Center. BJU Int 97(4): 711-715, 2006.

49 Guo AT, Chen W and Wei LX: Clinical and pathologic characteristics of small cell neuroendocrine carcinoma of urinary tract. Zhonghua Bing Li Xue Za Zhi 41(11): 747-751, 2012.

50 Thota S, Kistangari G, Daw H and Spiro T: A clinical review of small-cell carcinoma of the urinary bladder. Clin Genitourin Cancer 11(2): 73-77, 2013.

51 Prelaj A, Rebuzzi SE, Magliocca FM, Speranza I, Corongiu E, Borgoni G, Perugia G, Liberti M and Bianco V: Neoadjuvant chemotherapy in neuroendocrine bladder cancer: a case report. Am J Case Reports 17: 248-253, 2016.

52 Ghadouane M, Zannoud M, Alami M, Albouzidi A, Labraimi A, Safi L and Abbar M: Small cell neuroendocrine carcinoma of the bladder. A new case report Ann Urol (Paris) 37(2): 75-78, 2003.

53 Siefker-Radtke AO, Dinney CP, Abrahams NA, Moran C, Shen Y, Pisters LL, Grossman HB, Swanson DA and Millikan RE: Evidence supporting preoperative chemotherapy for small cell carcinoma of the bladder: a retrospective review of the M. D. Anderson cancer experience. J Urol 172(2): 481-484, 2004.

54 Manunta A, Vincendeau S, Kiriakou G, Lobel B and Guillé F: Non-transitional cell bladder carcinomas. BJU Int 95: 497-502, 2005.

55 Tunc B, Ozguroglu M, Demirkesen O, Alan C, Durak H, Dincbas FO and Kural AR: Small cell carcinoma of the bladder: a case report and review of the literature. Int Urol Nephrol 38(1): 15-19, 2006.

56 Ruoppolo M, Pezzica E, Milesi R, Corti D, Mercurio P and Fragapane $\mathrm{G}$ : Neuroendocrine small-cell bladder cancer: our experience. Urologia 77(17): 64-71, 2010.

57 Macedo LT, Ribeiro J, Curigliano G, Fumagalli L, Locatelli M, Carvalheira JB, Quintela A, Bertelli S and De Cobelli O: Multidisciplinary approach in the treatment of patients with small cell bladder carcinoma. Eur J Surg Oncol 37(7): 558562,2011 
58 Cerulli C, Busetto GM, Antonini G, Giovannone R, Di Placido M, Soda G, De Berardinis E and Gentile V: Primary metastatic neuroendocrine small cell bladder cancer: a case report and literature review. Urol Int 88(3): 365-369, 2012.

59 Aragón-Tovar AR, Pineda-Rodríguez ME, Puente-Gallegos FE and Zavala-Pompa A: Neuroendocrine carcinoma of the urinary bladder. A case report. Cir Cir 82(3): 338-343, 2014.

60 Erdem GU, Özdemir NY, Demirci NS, Şahin S, Bozkaya Y and Zengin N: Small cell carcinoma of the urinary bladder: changing trends in the current literature. Curr Med Res Opin 32(6): 1013-1021, 2016.

61 Coelho HMP, Pereira BAGJ and Caetano PAST: Large cell neuroendocrine carcinoma of the urinary bladder: case report and review. Curr Urol 7: 155-159, 2014.

62 Gupta S, Thompson RH, Boorjian SA, Thapa P, Hernandez LP, Jimenez RE, Costello BA, Frank I and Cheville JC: High grade neuroendocrine carcinoma of the urinary bladder treated by radical cystectomy: a series of small cell, mixed neuroendocrine and large cell neuroendocrine carcinoma. Pathology 47(6): 533$542,2015$.

63 Colarossi C, Pino P and Giuffrida D: Large cell neuroendocrine carcinoma (LCNEC) of the urinary bladder: a case report. Diagn Pathol 8: 19, 2013.

64 Zakaria A, Al Share B, Kollepara S and Vakhariya C: External beam radiation and brachytherapy for prostate cancer: Is it a possible trigger of large cell neuroendocrine carcinoma of the urinary bladder? Case Rep Oncol Med 2017: 1853985, 2017.

65 Evans AJ, Al-Maghrabi J, Tsihlias J, Lajoie G, Sweet JM and Chapman WB: Primary large cell neuroendocrine carcinoma of the urinary bladder. Arch Pathol Lab Med 126(10): 1229-1232, 2002.

66 Komiya A, Suzuki H and Imamoto T: Neuroendocrine differentiation in the progression of prostate cancer. Int J Urol 16: 37-44, 2009.

67 Terry S and Beltran H: The many faces of neuroendocrine differentiation in prostate cancer progression. Front Oncol 4: 60, 2014

68 Wright ME, Tsai MJ and Aebersold R: Androgen receptor represses the neuroendocrine transdifferentiation process in prostate cancer cells. Mol Endocrinol 17: 1726-1737, 2003.

69 Abstracts of the 27th annual meeting of the Italian Society of UroOncology (SIUrO). Anticancer Res 37(4): 2051-2158, 2017.

70 Hirano D, Okada Y, Minei S, Takimoto $\mathrm{Y}$ and Nemoto N: Neuroendocrinedifferentiation in hormone refractory prostate cancer following androgen deprivation therapy. Eur Urol 45: 586-592, 2004

71 Sasaki T, Komiya A, Suzuki H, Shimbo M, Ueda T, Akakura K and Ichikawa T: Changes in chromogranin a serum levels during endocrine therapy in metastatic prostate cancer patients. Eur Urol 48: 224-229, 2005.

72 Beltran H, Tomlins S and Aparicio A: Aggressive variants of castration-resistant prostate cancer. Clin Cancer Res 20(11): 2846-2850, 2014.

73 Parimi V, Goyal R, Poropatich K and Yang XJ: Neuroendocrine differentiation of prostate cancer: a review. Am J Clin Exp Urol 2(4): 273-285, 2014

74 Epstein JI, Amin MB, Beltran H, Lotan TL, Mosquera JM, Reuter VE, Robinson BD, Troncoso P and Rubin MA: Proposed morphologic classification of prostate cancer with neuroendocrine differentiation. Am J Surg Pathol 38: 756-767, 2014.
75 Cheville JC, Tindall D, Boelter C, Jenkins R, Lohse CM, Pankratz VS, Sebo TJ, Davis B and Blute ML: Metastatic prostate carcinoma to bone: clinical and pathologic features associated with cancer-specific survival. Cancer 95(5): 1028-1036, 2002.

76 Beltran H, Rickman DS, Park K, Chae SS, Sboner A, MacDonald TY, Wang Y, Sheikh KL, Terry S, Tagawa ST, Dhir R, Nelson JB, de la Taille A, Allory Y, Gerstein MB, Perner S, Pienta KJ, Chinnaiyan AM, Wang Y, Collins CC, Gleave ME, Demichelis F, Nanus DM and Rubin MA: Molecular characterization of neuroendocrine prostate cancer and identification of new drug targets. Cancer Discov 1: 487-495, 2011.

77 Clinicaltrials.gov, NCT01799278. Results first posted in 2017.

78 Stangelberger A, Schally AV, Letsch M, Szepeshazi K, Nagy A, Halmos G, Kanashiro CA, Corey E and Vessella R: Targeted chemotherapy with cytotoxic bombesin analogue AN-215 inhibits growth of experimental human prostate cancers. Int $\mathrm{J}$ Cancer 118: 222-229, 2006.

79 Dizeyi N, Bjartell A, Hedlund P, Taskén KA, Gadaleanu V and Abrahamsson PA: Expression of serotonin receptors 2B and 4 in human prostate cancer tissue and effects of their antagonists on prostate cancer cell lines. Eur Urol 47(6): 895-900, 2005.

80 Nelson PS: Molecular States Underlying Androgen Receptor Activation: A Framework for Therapeutics Targeting Androgen Signaling in Prostate Cancer. J Clin Oncol 30: 644-646, 2012.

81 Ghannoum JE, DeLellis RA and Shin SJ: Primary carcinoid tumor of the prostate with concurrent adenocarcinoma: a case report. Int J Surg Pathol 12: 167-170, 2004.

82 Tash JA, Reuter VE and Russo P: Metastatic carcinoid tumor of the prostate. J Urol 167: 2526-2527, 2002.

83 Reyes A and Moran CA: Low-grade neuroendocrine carcinoma (carcinoid tumor) of the prostate. Arch Pathol Lab Med 128(12): e166-168, 2004.

84 Palmgren JS, Karavadia SS and Wakefield MR: Unusual and underappreciated: small cell carcinoma of the prostate. Semin Oncol 34: 22-29, 2007.

85 Kawai S, Hiroshima K, Tsukamoto Y, Tobe T, Suzuki H, Ito H, Ohwada $\mathrm{H}$ and Ito $\mathrm{H}$ : Small cell carcinoma of the prostate expressing prostate-specific antigen and showing syndrome of inappropriate secretion of antidiuretic hormone: an autopsy case report. Pathol Int 53: 892-896, 2003.

86 Rueda-Camino JA, Losada-Vila B, De Ancos-Aracil CL, Rodríguez-Lajusticia L, Tardío JC and Zapatero-Gaviria A: Small cell carcinoma of the prostate presenting with Cushing Syndrome. A narrative review of an uncommon condition. Ann Med 48(4): 293-299, 2016.

87 Leibovici D, Spiess PE, Agarwal PK, Tu SM, Pettaway CA, Hitzhusen K, Millikan RE and Pisters LL: Prostate cancer progression in the presence of undetectable or low serum prostate-specific antigen level. Cancer 109: 198-204, 2007.

88 Beltran H, Tagawa ST, Park K, MacDonald T, Milowsky MI, Mosquera JM, Rubin MA and Nanus DM: Challenges in recognizing treatment-related neuroendocrine prostate cancer. $\mathrm{J}$ Clin Oncol 30: e386-389, 2012.

89 Yao JL, Madeb R, Bourne P, Lei J, Yang X, Tickoo S, Liu Z, Tan D, Cheng L, Hatem F, Huang J and Anthony di Sant'Agnese P: Small cell carcinoma of the prostate: an immunohistochemical study. Am J Surg Pathol 30: 705712, 2006.

90 Wang W and Epstein JI: Small cell carcinoma of the prostate. A morphologic and immunohistochemical study of 95 cases. Am J Surg Pathol 32: 65-71, 2008. 
91 Simon RA, di Sant'Agnese PA, Huang LS, Xu H, Yao JL, Yang Q, Liang S, Liu J, Yu R, Cheng L, Oh WK, Palapattu GS, Wei $\mathrm{J}$ and Huang J: CD44 expression is a feature of prostatic small cell carcinoma and distinguishes it from its mimickers. Hum Pathol 40: 252-258, 2009.

92 Guo CC, Dancer JY, Wang Y, Aparicio A, Navone NM, Troncoso $\mathrm{P}$ and Czerniak BA: TMPRSS2-ERG gene fusion in small cell carcinoma of the prostate. Hum Pathol 42: 11-17, 2011.

93 Deorah S, Rao MB, Raman R, Raman R, Gaitonde K and Donovan JF: Survival of patients with small cell carcinoma of the prostate during 1973-2003: a population-based study. BJU Int 109(6): 824-830, 2012.

94 Campedel L, Kossaï M, Blanc-Durand P, Rouprêt M, Seisen T, Compérat E, Spano JP and Malouf G: Neuroendocrine prostate cancer: Natural history, molecular features, therapeutic management and future directions. Bull Cancer 104(9): 789799, 2017.

95 Evans AJ, Humphrey PA, Belani J, van der Kwast TH and Srigley JR: Large cell neuroendocrine carcinoma of prostate: a clinicopathologic summary of 7 cases of a rare manifestation of advanced prostate cancer. Am J Surg Pathol 30: 684-693, 2006.

96 Koutsilieris M, Mitsiades C, Dimopoulos T, Ioannidis A, Ntounis A and Lambou T: A combination therapy of dexamethasone and somatostatin analog reintroduces objective clinical responses to LHRH analog in androgen ablation-refractory prostate cancer patients. J Clin Endocrinol Metab 86: 5729-5736, 2001.

97 Di Silverio F and Sciarra A: Combination therapy of ethinylestradiol and somatostatin analogue reintroduces objective clinical responses and decreases chromogranin a in patients with androgen ablation refractory prostate cancer. $\mathrm{J}$ Urol 170: 1812-1816, 2003.

98 Inoue S, Oka K, Araki T, Yano A, Tacho T, Fujii M, Kimoto K, Murakami M and Ohshiro Y: Neuroendocrine carcinoma of the prostate effectively treated by cisplatin and irinotecan - a case report. Gan To Kagaku Ryoho 34(8): 1323-1325, 2007.

99 Garcia JA and Danielpour D: Mammalian target of rapamycin inhibition as a therapeutic strategy in the management of urologic malignancies. Mol Cancer Ther 7(6): 1347-1354, 2008.

100 Maebayashi T, Abe K, Aizawa T, Sakaguchi M, Ishibash N, Fukushima S, Honma T, Kusumi Y, Matsui T and Kawata N: Solitary pulmonary metastasis from prostate cancer with neuroendocrine differentiation: a case report and review of relevant cases from the literature. World J Surg Oncol 13: 173, 2015.

101 Wei J, Zheng X, Li L, Wei W, Long Z and He L: Rapid progression of mixed neuroendocrine carcinoma-acinar adenocarcinoma of the prostate: A case report. Oncol Lett 12(2): 1019-1022, 2016.

102 Jung Y, Cackowski FC, Yumoto K, Decker AM, Wang J, Kim JK, Lee E, Wang Y, Chung JS, Gursky AM, Krebsbach PH, Pienta KJ, Morgan TM and Taichman RS: CXCL12 $\gamma$ promotes development of metastatic castration resistant prostate cancer by induction of cancer stem cell and neuroendocrine phenotypes. Cancer Res 78(8): 2026-2039, 2018.

103 Schneider A, Kollias A, Woziwodzki J and Stauch G: Testicular metastasis of a metachronous small cell neuroendocrinic prostate cancer after anti-hormonal therapy of a prostatic adenocarcinoma. Case report and literature review. Urologe A 45(1): 75-80, 2006.

104 Benchekroun A, Nouini Y, Zannoud M, Kasmaoui el H, Jira M and Iken A: Small cell carcinoma of the prostate: a case report Ann Urol (Paris) 36(5): 314-317, 2002.
105 Stein ME, Bernstein Z, Abacioglu U, Sengoz M, Miller RC, Meirovitz A, Zouhair A, Freixa SV, Poortmans PH, Ash R and Kuten A: Small cell (neuroendocrine) carcinoma of the prostate: etiology, diagnosis, prognosis, and therapeutic implications--a retrospective study of 30 patients from the rare cancer network. Am J Med Sci 336(6): 478-488, 2008.

106 Spieth ME, Lin YG and Nguyen TT: Diagnosing and treating small-cell carcinomas of prostatic origin. Clin Nucl Med 27(1): 11-17, 2002.

107 Papandreou CN, Daliani DD, Thall PF, Tu SM, Wang X, Reyes A, Troncoso P and Logothetis CJ: Results of a phase II study with doxorubicin, etoposide, and cisplatin in patients with fully characterized small-cell carcinoma of the prostate. J Clin Oncol 20(14): 3072-3080, 2002.

108 Berry W, Dakhil S, Modiano M, Gregurich M and Asmar L: Phase III study of mitoxantrone plus low dose prednisone versus low dose prednisone alone in patients with asymptomatic hormone refractory prostate cancer. J Urol 168: 2439-2443, 2002.

109 Lord R, Nair S, Schache A, Spicer J, Somaihah N, Khoo V and Pandha H: Low dose metronomic oral cyclophosphamide for hormone resistant prostate cancer: a phase II study. J Urol 177: 2136-2140, 2007.

110 Yashi M, Terauchi F, Nukui A, Ochi M, Yuzawa M, Hara Y and Morita T: Small-cell neuroendocrine carcinoma as a variant form of prostate cancer recurrence: a case report and short literature review. Urol Oncol 24(4): 313-317, 2006.

111 Uemura KI, Nakagawa G, Chikui K, Moriya F, Nakiri M, Hayashi T, Suekane S and Matsuoka K: A useful treatment for patients with advanced mixed-type small cell neuroendocrine carcinoma of the prostate: A case report. Oncol Lett 5(3): 793-796, 2013.

112 Aparicio AM, Harzstark AL, Corn PG, Wen S, Araujo JC, Tu SM, Pagliaro LC, Kim J, Millikan RE, Ryan C, Tannir NM, Zurita AJ, Mathew P, Arap W, Troncoso P, Thall PF and Logothetis CJ: Platinum-based chemotherapy for variant castrate-resistant prostate cancer. Clin Cancer Res 19: 3621-3630, 2013.

113 Aparicio A and Tzelepi V: Neuroendocrine (small-cell) carcinomas: why they teach us essential lessons about prostate cancer. Oncology (Williston Park) 28(10): 831-838, 2014.

114 Peverelli G and Grassi P: Pure small cell recurrent prostate cancer developing syndrome of inappropriate antidiuretic hormone secretion. Tumori 103: e56-e59, 2017.

115 Akamatsu S, Inoue T, Ogawa O and Gleave ME: Clinical and molecular features of treatment related neuroendocrine prostate cancer. Int J Urol, 2018. doi: 10.1111/iju.13526. [Epub ahead of print]

116 Okoye E, Choi EK, Divatia M, Miles BJ, Ayala AG and Ro JY: De novo large cell neuroendocrine carcinoma of the prostate gland with pelvic lymph node metastasis: a case report with review of literature. Int J Clin Exp Pathol 7(12): 9061-9066, 2014.

117 Sun F, Zhang ZW, Tan EM, Lim ZLR, Li Y, Wang XC, Chua $\mathrm{SE}, \mathrm{Li}$ J, Cheung $\mathrm{E}$ and Yong EL: Icaritin suppresses development of neuroendocrine differentiation of prostate cancer through inhibition of IL-6/STAT3 and Aurora kinase A pathways in TRAMP mice. Carcinogenesis 37(7): 701-711, 2016.

Received March 19, 2018

Revised April 17, 2018

Accepted April 18, 2018 